\title{
Contribuições Psicanalíticas à Clínica Médica na Atenção Primária à Saúde.
}

\author{
Furtado, Nathalia Vidigal; Mezan, Renato \\ Uninove — natyfurt@yahoo.com.br
}

Introdução: Diante de uma ampliação da noção de saúde adotada pelos serviços da área e considerando a Atenção Primária em Saúde (APS) como a grande possibilidade de enfrentamento dos problemas de saúde da população, faz-se necessário a discussão e articulação com outros campos de conhecimento que possam contribuir para o trabalho na Saúde e com respostas mais efetivas neste setor. Objetivos: o presente trabalho tem como objetivo estudar a prática clínica realizada por profissionais médicos no contexto dos serviços de APS, e pensar algumas possíveis contribuições ao tema a partir da Psicanálise, visando a uma discussão sobre aspectos sociais e subjetivos que se fazem presentes nesse campo. Método: Essa articulação foi construída utilizando a bibliografia da área e o material de entrevistas com dois profissionais médicos e três usuários/pacientes destes serviços. Resultados: Seguindo as trilhas de Balint, nossa hipótese é de que haverá sempre no espaço de uma relação como a do médico com o seu paciente, um lugar para a Psicoterapia, embora alguns contextos tenham um destaque especial. Acreditamos ser esse o caso dos serviços de APS, pois envolvem problemas com uma complexidade particular e a tarefa de compreendê-los deve ser perseguida antes de qualquer intervenção. Conclusão: Conclui-se que esta compreensão será alcançada, apenas, no momento em que a presença do paciente for considerada de maneira adequada. Essa mudança implica, necessariamente, em se reconhecer, concomitantemente, a presença da singularidade do profissional médico, sem a qual, nenhuma mudança é possível. Procuramos primeiro contextualizar a prática clínica na APS, destacando sua importância no processo de reorientação na lógica dos serviços de saúde, e resgatar o método de trabalho clínico, considerando as proximidades e divergências no campo da Medicina e da Psicanálise. na sequência, buscamos refletir sobre a necessidade da dimensão psicoterápica na prática da clínica médica, a importância das questões transferenciais na relação médico-paciente e sobre a necessidade de reconhecer a doença como construção particular/subjetiva de um sujeito, concebendo a clínica como uma prática de cuidado e de construção de sentido diante da experiência de adoecimento. a partir de um olhar psicanalítico, discutimos sobre o estatuto de corpo presente na Medicina, assim como o (en) laço social presente na clínica médica, considerando algumas questões presentes desde a formação médica até a prática clínica.

Furtado, Nathalia Vidigal; Mezan, Renato. Contribuições Psicanalíticas À Clínica Médica na Atenção Primária À Saúde.. In: Anais do Congresso Internacional de Humanidades \& Humanização em Saúde [= Blucher Medical Proceedings, num.2, vol.1]. São Paulo: Editora Blucher, 2014. ISSN 2357-7282

DOI 10.5151/medpro-cihhs-10606 